\title{
Disaggregating Opportunities: Opportunity Structures and Organizational Resources in the Study of Armed Conflict
}

John Gledhill (Department of International Development, University of Oxford)

For publication in Civil Wars (accepted September 2018).

\begin{abstract}
In studies of armed conflict and civil war, it is common to distinguish between explanations that focus on the motives of insurgents and accounts that examine opportunities for rebellion. But what do scholars actually mean by 'opportunities'? Some invoke the concept when referring to contexts in which states cannot suppress rebellion. For others, opportunities exist where insurgents have access to resources that facilitate the realization of collective violence. And a third group refers to 'opportunities' when discussing both of the above contexts. Across the field, then, the concept is used inconsistently. Consequently, I propose two conceptual clarifications. Drawing on insights from sociological literature, I argue that 'opportunities' should be disaggregated into two, more finite concepts: opportunity structures, understood as arrangements that inform externally-imposed constraints on insurgency; and organizational resources, understood as means that shape the internal capacity of armed groups. Second, I suggest that conflict scholars should consider both material/institutional and social/normative dimensions of each disaggregated concept. To illustrate the heuristic benefits of the proposed framework, I use it as a basis for exploring variation in collective violence in Albania during the 1990s. That variation appears puzzling when seen through aggregated lenses but is explicable when examined through disaggregated lenses.
\end{abstract}

Acknowledgements: Kind thanks to Sashenka Lleshaj for her invaluable research and translation assistance while I was collecting data for this article. I also thank Ariel Ahram, Shane Barter, Jörg Friedrichs, Ian Madison, James Pettifer, Oisín Tansey, anonymous reviewers, and the editors for their comments on earlier drafts of the study. All views, along with any unintended errors, omissions, or misrepresentations are, of course, my own. 


\section{Disaggregating Opportunities: Opportunity Structures and Organizational Resources in the Study of Armed Conflict}

In studies of the causes of armed conflict and civil war, it is common to distinguish between accounts that focus on the motives of actors who mobilize for violent rebellion, and explanations that explore opportunities for violent insurgency (e.g Cederman \& Vogt, 2017; Taydas et al., 2011). But what do conflict scholars actually mean by 'opportunities' for insurgency? Some invoke the term when referring to contexts in which state authorities are unable or unwilling to suppress armed groups ${ }^{1}$ (e.g. Fearon \& Laitin, 2003; Gleditsch \& Ruggeri, 2010; Hendrix 2010; Sobek, 2010). For others, opportunities exist when insurgents have access to resources that boost their capacity to organize and realize violent collective action (e.g. Collier \& Hoeffler, 2004; Le Billon, 2001; Adamson, 2005a; Lujala, 2010). And a third group invokes structures of opportunity when referring to both of the above contexts (e.g. Denny \& Walter, 2014; Basedau \& Lay, 2009; Greenhill \& Major, 2006/7; Ballentine \& Nitzschke, 2003). Across studies of armed conflict, then, the idea of 'opportunities' is used commonly, but inconsistently. This article aims to remedy that inconsistency by proposing two refinements to the way we use the term.

First, I suggest that 'opportunities' should be disaggregated into two, distinct concepts: 1) Opportunity structures for violent insurgency, understood as institutional and social arrangements that impose or lift external constraints on the possibility for violent rebellion; 2) Organizational resources for insurgents, understood as material and social means that boost the internal organizational capacity of a set of (non-state) actors to mobilize for, and realize, collective violence. In distinguishing between these concepts, I do not claim novelty. Rather, early scholars of social mobilization differentiated between external constraints on, and the internal capacities of, resistance movements. Over time, however, these two aspects of the feasibility of rebellion have become conflated under the broad banner of 'opportunities', particularly in the study of armed conflict. That tendency toward conflation, I suggest, should now be reversed.

My second proposal is that disaggregation should not stop at the meta-level distinction between opportunity structures and organizational resources. Rather, there is merit in distinguishing between material/institutional and social/normative dimensions of each

\footnotetext{
${ }^{1}$ Throughout the article, I refer to the violent actions of non-state 'armed groups', 'insurgents', and 'rebels' interchangeably. While I recognize that the terms are not wholly synonymous, my discussion of 'opportunities' is relevant to the activities of all three sets of non-state actors in a functionally similar way.
} 
disaggregated concept. Thus, a thorough understanding of opportunity structures should not only consider whether authorities have the material (i.e. coercive) capacity to impose external constraints on rebels, but also whether social norms, ideas, and discourses constrain or enable violent insurgency. Equally, a comprehensive understanding of organizational resources should not only explore whether prospective rebels have access to funds and arms, but also whether they have access to networks of social trust, communication, and ideas that can boost the capacity of non-state groups to organize and realize a violent collective action.

To illustrate the merits of disaggregation and specification, I use the proposed conceptual framework to 'make sense' of variation in the presence/absence of armed conflict in Albania at two points in the 1990s. In both 1991 and 1997, state capacity dissolved. However, there was no large-scale violence in 1991, while there was insurgency and collective violence in 1997. Seen through aggregated lenses, this variation is puzzling because state weakness created diverse 'opportunities' for organized violence on both occasions. By examining the cases through disaggregated lenses, however, that variation can be explained. Specifically, a disaggregated approach reveals that state weakness created opportunity structures that were conducive to armed insurgency in both 1991 and 1997; however, the material and social organizational resources needed for collective violence were absent in 1991 but present in 1997. Thus, a disaggregated approach suggests that the presence of organizational resources was a necessary condition for the outbreak of violent conflict in 1997, while the absence of resources for organized violence helped avert such an outcome in 1991.

In the sections that follow, I unpack my arguments in four steps. First, I present a brief overview of the evolution of 'opportunities' in the study of armed conflict by tracing the concept back to its origins in sociological literature on contentious politics. Arguing that the idea has been stretched -- particularly in the study of conflict and insurgency -- I then propose that the term should be disaggregated, and I offer stylized definitions of opportunity structures and organizational resources. In the third section, I use a disaggregated framework to explain variation in collective violence in Albania across the 1990s, before concluding by suggesting that conceptual clarification is not only important from an analytic perspective; rather, it could help render studies of armed conflict more policy-relevant.

\section{The Evolution of Opportunities in the Study of Armed Conflict}

Contemporary understandings of the role of opportunities in enabling armed conflict have their origins in intellectual debates that arose in the 1960s and '70s, when sociologists tried to account for a sharp rise in protest movements across the globe over previous decades - 
- ranging from the civil rights movement in the United States, to student protests in Europe, and anti-colonial resistance in Asia and Africa. Initial explanations of those movements started from the assumption that collective grievances drive contentious political action, and so early studies focused on identifying the motivations of protestors. Ted Gurr (1970) led the way on that front, arguing that individuals come together and "rebel" under conditions of "relative deprivation"; that is, when a gap opens up between actors' expected life chances and their actual circumstances. While this logic was influential, empirical tests quickly showed that there are many more deprived individuals than active protest movements, and so Gurr's focus on motivations was seen to be an insufficient explanation (see Snyder \& Tilly, 1972).

Consequently, scholars began to shift away from an exploration of why groups of actors are motivated to rebel, toward a focus on explaining when motivated groups might revolt. Two answers were proffered. One set of authors suggested that groups realize contentious political action when political opportunities are favorable to protestors; that is, when the risk of sanction from governing authorities is low and/or the possibility of shaping political outcomes through contentious political activity is high (see discussions of Lipsky and Eisinger in McAdam, 1996; and Opp, 2009, Ch.6). A second set of scholars argued that protests emerge when activists gain access to the resources they need to successfully organize, and sustain, a protest movement -such as funds and communications tools (Jenkins, 1983; McCarthy \& Zald, 1977). When these opportunity- and resource-focused accounts were introduced, they were sometimes seen as competing explanations of social mobilization and protest. From the late 1970s, however, arguments put forward by Charles Tilly (1977) and others challenged this agonism and, instead, suggested that the opportunity- and resource-based frameworks could be combined to produce synthetic explanations of when and how motivated groups mobilize for contentious political action.

The synthetic approach took off and, in effect, became the order of the day in the study of contentious politics during the 1980s and '90s (see McAdam, 1982/99; Tarrow, 1998). Arguably, however, the synthesis was not always balanced. Rather, a number of leading authors recognized the merits of a synthetic approach but emphasized the role of political opportunities in creating possibilities for contentious political action -- at the expense of giving equal discursive consideration to the role of resources (see discussions in Schock 2005, Ch.2; Opp, 2009, Ch.6). While that emphasis may have encouraged the development of parsimonious explanatory frameworks, it also meant that the language of 'opportunities' became increasingly common (or even dominant) in the field. That discursive commonality, in turn, seems to have underwritten a degree of conceptual "stretching" (Sartori, 1970), which saw causal dynamics 
that had previously been associated with resource-based approaches become gradually subsumed under the increasingly broad banner of 'opportunities' (and cognate terms) for collective resistance. Thus, by the late 1990s, critics were concerned that the idea of "political opportunity" was being used in reference to "virtually anything that, in retrospect, can be seen as having helped a movement mobilize or attain its goals" (Goodwin \& Jasper, 1999, 36). There was equal concern that, when the concept was "used to explain so much, it may ultimately explain nothing at all" (Gamson \& Meyer, 1996, 275). When the idea of 'opportunities' then gained currency in the study of conflict, this was arguably the case.

\section{'Opportunities' in the Study of Armed Conflict}

Just as a spike of social activism in the 1960s triggered the study of protest movements, so too did a spike in ethno-national civil wars in the early 1990s trigger increased interest in the causes and dynamics of armed conflict. And, just as early studies of protest movements had focused on motivations for activism, so too did accounts of armed conflict in the early-to-mid 1990s start by exploring the collective motives of belligerent parties (for contrasting perspectives see Huntington 1993; Turton 1997). In a further reflection of the social mobilization literature, however, conflict scholars soon recognized that there are far more (aggrieved) identity groups in the world than armed conflicts and, thus, intergroup animosity cannot be a sufficient condition for violent intergroup conflict (Fearon \& Laitin, 1996). Consequently, efforts to explain civil war began to look beyond the motives of rebels.

To expand the explanatory scope of their analyses, conflict scholars drew on ideas espoused in sociological and economic treatments of social protest which, as suggested, had come to embrace the idea that non-state actors act contentiously when (loosely-defined) opportunities for collective action arise. While there was certainly logic to that step, there were also associated complications because the concept of 'opportunities' had already been stretched in the literature on social mobilization, and it was used variably by economists. In theory, conflict scholars could have overcome this problem by specifying how 'opportunities' should be operationalized in the study of armed conflict. However, this was not the case. Rather, as James Fearon has suggested, “'opportunity structures' were never clearly specified for empirical examination in the case of civil war" (Fearon, 2005, 485). Consequently, conflict scholars began -- and continue -- to use 'opportunities' in various ways; some employing the term when referring to an absence of state-imposed constraints on rebellion (e.g. Ron, 2005; Sobek, 2010), others invoking the concept when referring to factors that strengthen the capacity of non-state actors to realize a rebellion (e.g. Le Billon, 2001; Lujala, 2010), and still others 
using the term in reference to diverse influences on the feasibility of insurgency (Kuhn 2018, 390; Taydas et al, 2011; Denny \& Walter, 2014). This inconsistent use of the term, I propose, creates at least two problems for opportunity-based approaches to the study of conflict.

First, conceptual inconsistency arguably undermines the explanatory clarity -- and leverage -- of opportunity-based approaches to the study of insurgency and civil war, broadlyspeaking. After all, if the idea of 'opportunities' is used in reference to a diverse set of causal conditions, which trigger an equally diverse set of causal processes, then the widely-accepted premise that the development of opportunities for insurgency is a cause of armed conflict actually tells us little about when, why, and how that might be the case. In practice, of course, most studies that take an opportunities-based approach do not make such a sweeping claim. Rather, they explore how particular material, institutional, and social variables shape the capacity of states to repress rebels and/or the capacity of insurgents to stage a rebellion. Still, the discourse of 'opportunities' is now common, and so discrete causal claims are often aggregated (by authors themselves or outside readers) under the broad umbrella of opportunitybased arguments (e.g. Taydas et al, 2011; Cederman \& Vogt, 2017; Denny \& Walter, 2014). Where that is indeed the case, specific claims lose leverage as they become subsumed under the broad and imprecise argument that motivated actors realize collective violence when there are opportunities to do so.

A second (and related) problem with conceptual inconsistency is that very diverse sets of explanations of rebellion and conflict are labelled as opportunity-based arguments (again, by authors themselves or outside readers) and, as a result, causal accounts that are potentially complementary are sometimes seen as competing versions of opportunity-based claims. Take debates over the relationship between natural resources and armed rebellion. Fearon \& Laitin (2003) have argued that the presence of such resources can contribute to the creation of rentier states that have low capacity to repress rebels, which opens up opportunities for insurgency. By contrast, Collier and Hoeffler (2004) have suggested that natural resources offer insurgents sources of lootable wealth, which create opportunities for insurgency by allowing rebels to acquire the human and military resources needed to sustain an armed revolt. While evidently different in casual logic, both approaches are framed in terms of loosely-defined opportunities and, as such, they are often cast as rival interpretations (see Sambanis, 2004; Humphreys, 2005; Lujala, 2010; Ross, 2004). However, they are not. Rather, if the first is seen to show how natural resources can open up the possibility of insurgency by weakening state-imposed constraints on rebellion, while the second explains how motivated actors can access resources that allow them to exploit that possibility, then the two approaches become complementary. 


\section{Disaggregating 'Opportunities' in the Study of Armed Conflict}

If the idea of 'opportunities' has been stretched in a way that limits the analytic potential of opportunity-based approaches to studying armed conflict, then the concept underwriting those approaches would benefit from clarification, specification, and regularization. While this could be realized in various ways, consideration of John Gerring's (1999) guidelines for good concept formation points to two particular conceptual reforms.

First, if the term 'opportunities' is used inconsistently, then there is merit in replacing the stretched concept with one or more terms that are suitably "coherent" (i.e. they isolate a 'core' meaning) and "differentiated" (i.e. they are distinct from cognate concepts) (Gerring 1999, 374-76). I propose that the most familiar, resonant, and parsimonious way to realize these goals (see Gerring, 1999, 367) is to disaggregate 'opportunities' into: (1) Opportunity structures, which are arrangements that inform the presence/absence of external constraints on the realization of armed insurgency; (2) Organizational resources, which are means that determine the internal capacity of a rebel group to mobilize for, and realize, collective violence. As suggested at the outset, such a distinction is not novel. Rather, political sociologists studying mobilization have previously distinguished between external structural constraints on collective action and the internal organizational capacities of protest movements (Tilly, 1977; Kitschelt 1986; Koopmans, 1999; Meyer \& Minkoff 2004). While some conflict scholars have recognized that distinction (e.g. Asal et al. 2013; Weinstein 2007; della Porta 2008), many have not, and so incorporating it into the study of armed conflict would be a progressive step.

Any effort to replace 'opportunities' with alternate concepts should evidently be careful to specify the key characteristics of those concepts. Thus, I propose recognizing two dimensions of each disaggregated term: material/institutional and social/normative. In terms of opportunity structures, this means recognizing that the degree of external constraints on rebellion can be influenced by the repressive capacity of governing authorities and by norms and cultural practices that circulate in societies where potential rebels are operating. In terms of organizational resources, this means considering the access of insurgents to arms and money as well as their access to the networks of social trust and in-group ideas that facilitate mobilization for armed insurgency. As with my call for disaggregation, this distinction is not novel; rather, it also builds on conceptual treatments of opportunities (and similar terms) in the study of social movements (e.g. Gamson \& Meyer, 1996; Koopmans, 1999; Giugni 2009). Those studies have received limited attention in the conflict literature, however. As such, I go on to show how ideas drawn from the social movements literature can help us refine definitions of opportunity structures and organizational resources in the study of armed conflict. 


\section{Opportunity Structures for Insurgency}

As suggested, opportunity structures for insurgency can be understood as institutional and social arrangements that impose or lift external constraints on the capacity of non-state actors to mobilize for, and realize, collective violence.

External constraints are often understood in material/institutional terms, with the most commonly-cited determinant of such constraints being the will and capacity of governing authorities to suppress armed (non-state) actors. When authorities have sufficient military capability to quash a rebellion, and a willingness to use that capability, opportunity space is narrow. By contrast, when authorities are not willing or able to suppress armed groups, structures of opportunity favor insurgency. When considering repressive capacity, scholars typically focus on whether states are able to monopolize force and, thus, suppress violence from non-state actors. In so doing, they consider factors such as overall state capacity (Fearon and Laitin, 2003; Sobek, 2010), the institutional coherence of the government and military (Goldstone et al., 2010; Russell in Herbst, 2004, 358), regime type and stability (Hegre et al., 2001; Gledhill, 2013), topography (Buhaug et al. 2009), and beyond. Such a state-centric focus is not unreasonable, but it is important to also think beyond the state since diverse foreign powers, supranational organizations, international non-governmental organizations, and subnational informal governors can also shape the nature of externally-imposed constraints on (violent) collective action (della Porta 2008, 224-25; also see Keck and Sikkink, 1998). Where third parties offer support to states that are looking to suppress insurgent groups, for example, opportunity structures narrow (Tansey, 2016, Ch. 5). By contrast, where third parties withdraw existing support for a state, or actively try to undermine a state's capacity to maintain its monopoly on the use of force, opportunity space for insurgency expands (McAdam et al., 2001, Ch. 7).

Beyond military/institutional factors, the possibility for armed insurrection is also informed by the broad social/normative context in which potential insurgents are operating (see Gamson and Meyer, 1996). Thus, a thorough conceptualization of opportunity structures should include consideration of "discursive opportunities" -- public discourse and social norms that influence whether calls to mobilize for violent rebellion are likely to be welcomed or repudiated by potential insurgents (see Koopmans \& Olzak, 2004; McCammon et al., 2007; Giugni, 2009; Adamson, 2005b). On one hand, where there is widespread societal rejection of violence as an instrument for gaining power or profit, potential insurgents may not even consider the possibility of violent collective action and, if they do, fear of social sanction for violating norms may warn them off pursing such a strategy (see Sharp, 1959). On the other 
hand, society-wide acceptance of bellicose ideas, belief systems, discourses and other "aspects of...the symbolic sphere of our existence" may serve to normalize and legitimize the idea of violence as an instrument (Galtung, 1990, 291). Where public discourse does indeed feed such a normalization, individuals may see few moral barriers to the instrumental use of violence, and the society in which those individuals are embedded may see limited reason to sanction such behavior. Both dynamics can lift erstwhile social constraints on violence, thereby opening up structures of opportunity for violent collective action. ${ }^{2}$

\section{Organizational Resources for Insurgents}

Organizational resources for insurgents can be understood as material and social means that are available to groups of non-state actors, which shape the internal capacity of those groups to organize and realize violent collective actions.

Scholars who have considered the role of resources in facilitating insurgency have typically assumed that rich rebels are strong rebels, while poor insurgents are weak insurgents. ${ }^{3}$ Consequently, the concept of resources in the study of armed conflict is often associated with the access of rebels to sources of finance that allow them to purchase arms and maintain militants. As a result of that association, scholars have investigated -- and identified -- various sources of rebel finance. Thus, we now know that some non-state armed groups accrue funds in similar ways to states; that is, they collect 'taxes' from populations that fall within their spheres of control (Cramer, 2006, 183; Ahram, 2014). On other occasions, violent non-state groups act more like illicit private corporations, extracting natural resources and/or producing goods and then trading them on the global (black) market (Collier et al., 2009; Cramer, 2006, 172-73). On other occasions still, insurgents gather funds and military support through contributions from local supporters, diaspora communities, or sympathetic foreign states (Adamson, 2005a; Bakke, 2013). And, finally, the old adage of 'looting and plundering' continues to hold true, as those activities remain a steady source of finance and arms for violent non-state groups (Kaldor, 2006).

While finance and material resources clearly influence the internal capacity of rebel groups, we should recognize that there is also a social/normative dimension to organizational resources. This has been made clear in recent explorations of the micro-processes of

\footnotetext{
${ }^{2}$ It is important to apply this logic with a critical eye because a poorly-considered attribution of individual or group behavior to social discourse and norms runs the risk of constituting an ecological fallacy, at best, and cultural determinism, at worst.

${ }^{3}$ For a critique of this assumption, see Weinstein (2007).
} 
mobilization and violence (e.g. Weinstein, 2007; Driscoll, 2015; Staniland, 2012; Pearlman, 2011), which have demonstrated what scholars of social mobilization have long known -- that the capacity of non-state actors to mobilize for, and execute, collective action is shaped by their access to ready-existing societal organizations, social networks, and shared ideas (McAdam, 1982/99; Oberschall in Tilly, 1977). In terms of mobilization, the networks of trust that bind members of tight-knit social organizations -- such as ethnic groups, trade unions, sports clubs, and beyond -- are known to increase the willingness of members to join high-risk, violent collective actions (Asal et al., 2014; della Porta, 1988; Petersen, 2001). Once mobilized, strong social ties then facilitate within-group communication and, thus, the coordination of insurgent activities (McDoom, 2014, 886-87; Parkinson, 2013). Finally, ideas and ideologies that are shared exclusively among members of a closed group (as opposed to broad, society-wide norms) can also contribute to the organizational coherence of that group, and particularly bellicose ideologies may increase the willingness of group members to use violence in support their organization's purported goals (Sanín \& Wood, 2014).

\section{The Heuristic Value of Disaggregation and Specification}

The conceptual sketches offered (summarized in Figure 1, below) should be seen as "ideal types", which abstract "outstanding features from [a]...historical complex" in order to provide a "bird's eye view of the broad characteristics" of the concepts at hand (Watkins, 1952, 23-24). Thus, they are theoretical abstractions of opportunity structures and organizational resources, which aim to highlight the core principles of each concept rather than present a comprehensive empirical portrait of the two terms under consideration. In particular, the sharp differentiation between external constraints and internal capacities is somewhat stylized and, in practice, the line between (external) opportunity structures for insurgency and the (internal) organizational resources of rebel groups is less clear cut than the above articulations might suggest. While that stylization may limit the utility of the proposed concepts as descriptive tools, accentuating the key causal mechanisms that are associated with opportunity structures and organizational resources, respectively, boosts the utility of those concepts as heuristic tools for investigating and explaining armed conflict (based on Weber, 2004, 387-404). To that end, I suggest that there are two particular heuristic benefits to the proposed conceptual framework. 
Figure 1: Conceptual Disaggregation, and Specification of Dimensions

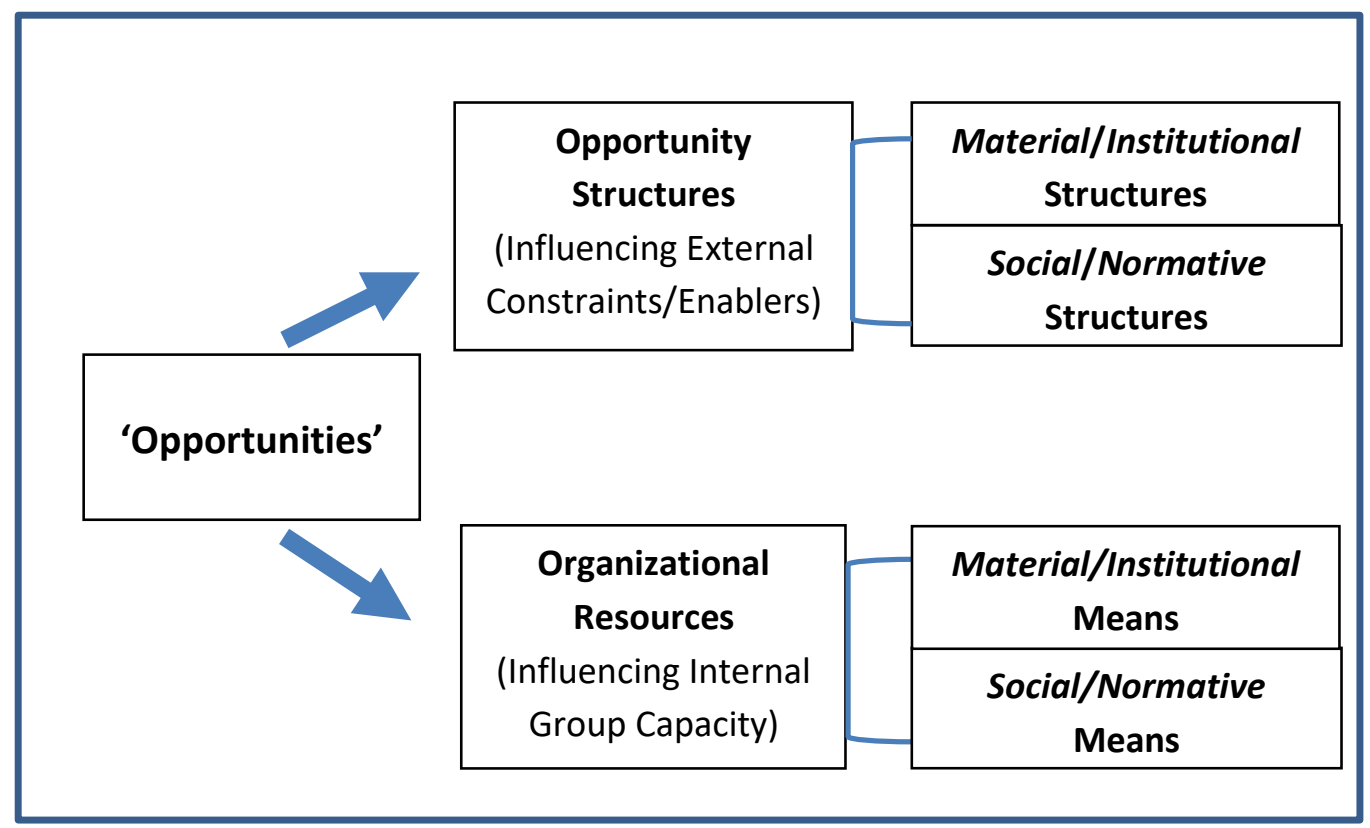

First, the adoption of highly-differentiated concepts of 'opportunity structures' and 'organizational resources' can help unearth a series of causal questions that remain obfuscated when the two concepts are aggregated under the broad banner of 'opportunities'. Specifically, where the conceptual line between external constraints and internal capacities is drawn sharply, it becomes possible to ask questions about the distinct causal contributions of opportunity structures and organizational resources to armed rebellion by investigating whether dimensions of each causal category are: a) necessary; b) sufficient; or c) "insufficient but necessary part[s] of a condition which is itself unnecessary but sufficient" for the onset and perpetuation of armed activity (Mackie in Mahoney, 2008, 418, emphasis in the original). Equally, a clear conceptual distinction between (external) opportunity structures and (internal) organizational resources can enable investigation of interactions between dimensions of the two categories by facilitating consideration of whether: (a) a weakening of external constraints on rebels might allow them to access resources that would, in turn, boost their capacity to realize armed insurgency; and (b) well-resourced rebels might use their strong organizational capacity to weaken externally-imposed constraints on their activities, thereby expanding opportunity space for insurgency. Clear differentiation can also facilitate consideration of interaction between opportunity structures, organizational resources, and collective motives for violence (which remain an essential pillar of investigation, although they cannot be deeply explored here).

Second, while a disaggregated conceptual framework can invite consideration of new causal questions, systematic consideration of the material/institutional and social/normative 
dimensions of the two proposed concepts can facilitate efforts to answer those questions. At present, considerations of (broadly-understood) opportunities for insurgency often focus narrowly on the material/institutional dimensions thereof -- factors that shape the relative coercive capacities of states and rebels. Of course, such factors matter. But they are not the whole story. Rather, as argued above, external constraints on insurgency and the internal capacity of rebels can be equally informed by social and normative contexts. By writing social/normative dimensions into the very definitions of opportunity structures and organizational resources, respectively, the proposed conceptual framework encourages scholars to systematically consider institutional/material and social/normative causes of conflict. For qualitative scholars, the inclusion of socially-informed variables would facilitate the production of narratives that better reflect the complex and diverse causal processes that underwrite the onset of armed rebellion. And for quantitative scholars, the inclusion of proxies for social and normative influences on insurgency could expand the explanatory scope of statistical models and, in so doing, minimize the risks that come with omitting key variables.

To illustrate the proposed benefits of conceptual disaggregation and specification, the next section uses a disaggregated framework to explain why there was little or no collective violence when the Albanian state became dysfunctional in 1991, but insurgency and large-scale violence broke out when the state dissolved again in 1997. The Albanian cases were chosen because that variation is puzzling when seen through aggregated opportunity-based lenses, but explicable when the two cases are analyzed through disaggregated lenses. Specifically, disaggregation shows that there were opportunity structures for collective violence in both 1991 and 1997, due to a breakdown in the capacity of the state to repress armed groups. However, while motivated actors in 1997 were able to access material and social means that allowed them to organize and realize acts of collective violence at that time, a lack of organizational resources in 1991 contributed to a near absence of organized violence.

Drawing on diverse sources, including field-based interviews, ${ }^{4}$ I work through each case; first offering background and noting grievances, then examining material/institutional and social/normative opportunity structures and, next, assessing the presence or absence of organizational resources for insurgency. Finally, I look at how motives, opportunity structures, and organizational resources interacted to produce the varying outcomes observed in the two cases.

\footnotetext{
${ }^{4}$ All interviews were conducted by the author in Tirana, Albania, in July 2014. Some interviews were conducted through a translator.
} 


\section{Case 1: Opportunity Structures without Organizational Resources - Albania $1991^{5}$}

\section{Background and Grievances}

Under the long-term dictatorship of Enver Hoxha (1944-85), Albania played host to the most extreme of all communist regimes in Europe (Tarifa, 1994, 62). All civil society was crushed, private economic activity was outlawed, and no form of political dissent was tolerated (Birch, 1971; Turku, 2009, Ch.4). Indeed, such was the level of state control that some observers have described communist Albania as Europe's version of North Korea (Gonce, 2009). Whether or not that was the case, it is clear that the state held total control under Hoxha, whose dictatorship was underpinned by an extremely repressive secret service -- the Sigurimi -- which established vast surveillance networks, imprisoned dissidents, and controlled all public information (Library of Congress, 1994, 227-28).

After Hoxha's death in 1985, his successor -- Ramiz Alia -- began to loosen the state's grip on society, albeit only slightly (Library of Congress, 1994, 228-29; Vickers \& Pettifer, 1997, Ch. 2). Thus, when students and intellectuals began to call for reform in late 1990, Alia proved willing to introduce elections, which were scheduled for March 1991. Surprisingly, perhaps, the incumbent communists won that ballot due to strong levels of support in the countryside (T. Smith, 1991), where it was more popular than the reformist Democratic Party, which had gathered under the leadership of Sali Berisha. Urban voters were unwilling to accept the communists' retention of power, however, and so groups of youths soon took to the streets in protest. A strike followed and, ultimately, the communist government gave way to mounting domestic and international pressure by resigning in June 1991, bringing an abrupt end to decades of communist rule (Fuga, 2003, 138-41).

Between June 1991 and March 1992, Albania weathered a period of institutional and governmental uncertainty; first, the elected communist government was forced from power (Traynor, 1991a); then a provisional "Government of National Stability" broke down due to internal disagreements (Vickers, 2009, 230); and, finally, a technocratic government was installed without a clear popular mandate. As governments came and went in this way, the authority of governing elites weakened, which undermined their capacity to manage state institutions. Consequently, state organs stopped providing basic public services, including electricity (Vickers \& Pettifer, 1997, 75), water (Fowler, 1992; H. Smith, 1991), and garbage

\footnotetext{
${ }^{5}$ Sections of this case study relate to my discussion of state capacity in transitional Albania (Gledhill 2017).
} 
collection. ${ }^{6}$ Unsurprisingly, the failure of public service provision generated widespread grievances and increasing disregard for the institutions of a dissolving state.

\section{Opportunity Structures in Albania, 1991}

Across the course of 1991 and into 1992, Albania's state security forces became dysfunctional. This weakened the capacity of authorities to maintain their monopoly on force and, in so doing, opened up material/institutional opportunity space in which insurgency became possible. Discipline and civilian control became an issue in the military, in particular (Zanga, 1991), after governments repeatedly failed to live up to commitments to improve soldiers' wages and poor living conditions. ${ }^{7}$ Internal divisions also reportedly opened up between army recruits who backed political change and those who were against it (Traynor, 1991b) ${ }^{8}$ Facing a bleak future, some conscripts chose to simply desert their posts and join the flow of migrants heading to Italy in search of refuge. Secret service officers, meanwhile, went to ground after the Sigurimi was formally dissolved in July $1991 .^{9}$ The regular police forces were left intact but they had not been as well funded or trained as the secret services during the period of communist rule and, as such, they struggled to manage the rise in crime that accompanied the fall of oppressive structures (Dine, 1991). ${ }^{10}$ Indeed, by early 1992, the police had become so ineffective that police chief Fadil Canaj declared that he did not have the forces he needed to control the "angry masses" and, as such, "the general situation in Albania [had become] anarchic" (Reuters, 1992).

While it is clear that the collapse of state capacity weakened institutional constraints on collective violence in 1991 , it is more difficult to assess the degree to which societal structures and discursive practices constrained or enabled violence at the time. Still, an interpretative reading suggests that societal constraints were limited. To be sure, there was a history of societal self-governance in Albania (Celik \& Shkreli, 2010; Bardoshi, 2012) and, in theory, the social codes guiding that self-governance could have provided a basis for regulating -- and pacifying -- behavior when state structures weakened in 1991. In practice, however, communist authorities had worked hard to crush any challenges to their authority and, as such, they had systematically repressed societal codes and associated structures of informal

\footnotetext{
${ }^{6}$ Based on an interview with a former government minister, now economist.

${ }^{7}$ Interview with a senior figure in the Ministry of Defense during the period of transition.

${ }^{8}$ Interview with an academic from the National Defense Academy.

${ }^{9}$ Based on an interview with a former ambassador.

${ }^{10}$ Based on an interview with a former senior government figure, now writer.
} 
governance (Sadiku, 2014; Fischer, 1999). Thus, by the time communist rule collapsed, traditional law had limited influence over the behavior of individuals, including their potential to use violence for instrumental purposes. And even if customary codes had carried influence, it is not certain that they would have placed societal constraints on collective violence. After all, traditional social sanctions in Albania included the right to revenge killings under the institutionalized terms of blood feuding (Celik \& Shkreli, 2010), and so a reliance on societal norms may have actually encouraged and legitimized, rather than constrained, the use of violence by non-state actors.

\section{The Absence of Organizational Resources in Albania, 1991}

While structures of opportunity rendered armed insurgency and other forms of collective violence possible in transitional Albania, organizational resources that are seen to facilitate mobilization for, and realization of, collective violence were not present at that time.

On the social side of the equation, Albania did not play host to the dense networks of trust that can enable the mobilization of armed groups -- simply because forty five years of state repression had served to completely atomize the local population. That atomization had been driven by a systematic destruction of independent associational life (Turku, 2009, 85-89); opposition parties had been outlawed, religion banned, and all civic associations had been brought under the control of authorities through the creation of state-sponsored 'mass organizations' such as women's associations, youth movements, and workers' unions. Officially, these associations promoted civic life. In practice, however, the (communist) Party of Labor used them as vehicles for expanding the reach of their surveillance networks into all corners of society. ${ }^{11}$ Such a penetration of society by the state severed horizontal social ties and broke down all networks of social trust and communication (Amy \& Gjermeni, 2013, 810). Consequently, by time the communist regime collapsed in 1991, Albanian society was completely fractured and mistrust was rife.

Material resources for armed collective action were also in scarce supply in 1991-92. Most immediately, there were few funds available to support the mobilization of armed groups. The state had held all resources during the communist period (Turku, 2009, 88), and so there were no private sources of income that could have been 'taxed' or extorted by potential militants. Nor could any such actors have gained significant profit by expropriating state resources because the country's already-poor nationalized industrial and agricultural sectors

\footnotetext{
${ }^{11}$ Interviews with a local journalist, a former ambassador, and a former senior government figure, now writer.
} 
ground to a halt alongside the dissolution of communist rule (Pashko, 1993). In the absence of access to funds, any proto-militants would have struggled to access arms through the global black market. At the same time, there were no arms available locally; hundreds of state armories were littered around the country but they remained under the watch of a handful of state troops in $1991,{ }^{12}$ even as the state organs that housed those troops became dysfunctional.

\section{The Outcome: An Absence of Armed Conflict}

The dissolution of state capacity brought severe human insecurity to transitional Albania. However, there was no armed insurgency or sustained collective violence at the time. The most common explanation for that outcome is that no groups were willing to use collective violence as a tool for political gain or profit. While that was demonstrably true, there was a sharp increase in levels of individual, criminal violence as state capacity withered in 1991, including attacks on state-owned factories, hospitals, shops, schools, and even nurseries (Fuga, 2003, 138-39). There was also a sharp increase in the frequency and intensity of interpersonal violence (Battiata, 1992). These trends suggest that a sizable number of individuals were ready to use violence in instrumental ways. The puzzle, then, is why individual willingness did not translate into the mobilization of armed groups -- either in support of predatory goals, or as means of protecting against such predation.

Having disaggregated opportunity structures and organizational resources, it seems that a lack of the material and social resources needed for collective violence contributed to the absence of that outcome in 1991. Most immediately, the material resources for insurgency -funds and arms -- were not widely available. More profoundly, however, four decades of extreme totalitarian rule had broken down networks of social trust in Albania, and this seems to have inhibited the mobilization of armed groups in the immediate post-communist period. ${ }^{13}$ The constraining effects of social atomization on mobilization can be indirectly gauged by noting an absence of the kinds of armed groups that typically emerge "when states fail" (Rotberg, 2004, 5-6). For example, although the collapse of Albania's military and police lifted external constraints on the possibility for organized criminal groups to pursue predatory goals, very few (if any) such groups actually formed immediately after the fall of the communist government. ${ }^{14}$ Nor did individuals organize into armed vigilante groups to protect their houses

\footnotetext{
${ }^{12}$ Interview with a senior figure in the Ministry of Defense during the period of transition.

${ }^{13}$ The author was given related explanations in an interview with a local university professor, and in written communication with a former government minister, now economist.

${ }^{14}$ Interviews with a member of parliament, and a senior early figure in the Democratic Party.
} 
and neighborhoods from the sharp increase in unorganized crime.${ }^{15}$ Rather, as one interviewee suggested, "there was no community protection" because Albanians "didn't have a sense of community" at the time. ${ }^{16}$ Such a lack of communal ties also seems to have acted as a barrier to the mobilization of armed groups around ethno-regional identities,${ }^{17}$ despite the existence of loosely-defined northern and southern regional identities, which may have been manipulated in support of mobilization if there had been strong networks of trust within those groups. But there were not. Instead, the only social ties that could have underwritten mobilization were political loyalties to the outgoing government, on one side, and reformist groups, on the other. Significantly, there were reports in early 1991 that partisan militants were organizing to defend the outgoing regime (Traynor, 1991c; Binder, 1991). However, it seems that social atomization ultimately blocked the realization of any such efforts since there is little evidence of sustained militia activity at that time.

Ultimately, in the absence of organizational resources for mobilization, armed groups did not form in transitional Albania in order to exploit the emerging opportunity structures for violence. And since there were no armed groups, there was no armed conflict. When the state folded again in 1997, however, the story was different.

\section{Case 2: Opportunity Structures with Organizational Resources - Albania 1997}

\section{Background and Grievances}

In March of 1992, a fresh set of elections was run in Albania. They were dominated by the Democratic Party (DP), which went on to form a government under the leadership of Prime Minister Aleksander Meksi and President Sali Berisha. Some reforms soon followed, as the new government worked with the International Monetary Fund to introduce liberalizing changes; price controls were dropped, industry and agriculture were privatized, and a taxation system was put in place (Bezemer, 2001, 1-3; Watson, 1997, 16-17). Civil society also grew after the totalitarian yoke was lifted; religious groups were permitted and diverse, issue-specific civil society associations formed (Amy \& Gjermeni, 2013).

Political pluralism and a free media, by contrast, were slower to develop, which led to concerns over Berisha's commitment to liberal democracy (see Kubicek, 1998). There were also fears that he was putting politics ahead of prudence when it came to financial regulation,

\footnotetext{
15 Interview with a local expert in international affairs.

${ }^{16}$ Interview with a local journalist.

17 The absence of such mobilization was reported during interviews with a former government minister now economist, a local academic, and a former ambassador.
} 
especially in relation to the governance of pyramid schemes, which grew rapidly in size, scope, and number in the mid-1990s. Despite being warned of the danger of such schemes by the World Bank and IMF in 1996, the DP government took few steps to curtail the bogus firms (Jarvis, 2000). To the contrary, the government seemed willing to support the schemes (Lubonja, 1997, 87) -- possibly because some were allegedly funding the DP (Musaraj, 2011, 101-02), and possibly because the government was unwilling to shut down popular schemes in an election year. Either way, Albania's pyramid firms were destined to go bust. And so they did, starting from January 1997, when a company known as Sude declared bankruptcy, owing its investors $\$ 38$ million (Abrahams, 2015, 179). Over the weeks and months that followed, one scheme after another folded. Since vast numbers of Albanians had invested in the firms, many families in Albania soon lost all savings they had accumulated over the previous five years (Korovilas, 1999). Unsurprisingly, popular sentiment then turned against the government.

\section{Opportunity Structures in Albania, 1997}

The sudden collapse of pyramid schemes opened up material/institutional opportunity structures for insurgency in Albania by triggering a collapse of the government's capacity to deploy, command, and control the country's security services (see Pettifer \& Vickers, 2007, Ch. 2). There was a particular loss of control over the military, which had been under-resourced for years and whose troops were poorly paid (Lane, 1998). That neglect meant that sympathy for Berisha and the DP government was already thin within the military before the financial crash. When pyramid schemes then began folding, some soldiers simply abandoned the government altogether (Behrakis, 1997; Daly, 1997). On occasion, desertion involved heading home to defend families amidst growing insecurity (Pettifer \& Vickers, 2007, 43). And, on other occasions, defection took the form of active attacks on government and state facilities, including police and military bases (Santoro, 1997). Regardless of the mode of desertion, however, it was clear that the government could not rely on the military or, indeed, the police by late March 1997. This was openly recognized by Berisha, who declared: “...we have no army...We have no police." (Nordland \& Sullivan, 1997). Thus, there were few external institutional constraints on the possibility for insurgency.

It is (again) more difficult to gauge whether societal practices and associated discourses created social/normative opportunity space that was conducive to collective violence in 1997. It is clear that certain societal codes of behavior that were circulating in the mid-1990s accepted -- or even encouraged -- the use of violence by non-state actors. This was particularly the case 
for blood feuding, which had resurfaced as a form of deterrence-based self-governance in regions where the state had struggled to assert its authority (Fischer, 1999, 296-97; Lawson \& Saltmarshe, 2000, 138). In addition to legitimizing acts of violence that were directly tied to blood vendettas, the return of feuding also created a discursive environment in which it arguably became possible for predatory actors to justify the use of violence for instrumental purposes (Schwandner-Sievers 2001). Still, the possibility for such a manipulation would have been largely restricted to peripheral northern regions of the country, where feuding was concentrated. Outside of those areas, violence remained exceptional, rather than normal. To be sure, a number of large-scale organized criminal groups had formed over the years following the dissolution of communist rule (Chassagne \& Gjeloshaj, 2001), and it is possible that the threats they posed to security partly normalized societal attitudes toward the use of violence. But it is equally possible that the sense of insecurity that accompanied the rise of organized criminal groups hardened attitudes against non-state violence.

\section{Organizational Resources in Albania, 1997}

When state organs collapsed in 1991, there had been few societal networks around which groups of actors could have mobilized for insurgency. And even if militants had been willing and able to come together, there would have been few arms available to them. The situation in 1997, however, was different on both fronts.

In terms of the social dimensions of organizational resources, both civil and 'uncivil' societal associations had formed in Albania over the six years that followed the end of totalitarian rule (Amy \& Gjermeni, 2013), and a number of those associations were characterized by the kind of within-group trust that can underwrite mobilization for risky collective action. A high degree of trust and reciprocity was re-established among members of kin and clan groups, in particular, as extended family ties became central to individuals' economic and social opportunities. Regional kinship ties, in turn, mapped onto political party networks; in northern regions, kin groups aligned with the Democratic Party, while familial networks in the south rallied behind the Socialists (Gërxhani \& Schram, 2000). Kinship also facilitated the formation of highly organized criminal groups (Irrea, 2006; Raufer, 2003), whose ranks were reportedly bolstered by the involvement of communist-era secret service officers (Chassagne \& Gjeloshaj, 2001). As these organized criminal groups consolidated, their members no doubt also developed their own -- dark -- form of within-group trust.

The material resources needed for armed rebellion also became widely available in early 1997, as state armories dotted around the country were raided by diverse actors. On 
occasion, those raids were facilitated by the fact that state guards deserted their posts (Fischer, 2010, 430). But even when guards remained in situ, the "nineteen-year-old boys who were poorly equipped and barely paid" proved incapable of holding back groups of marauding criminals and/or anti-government protestors (Abrahams, 2015, 189-90). As those attacks unfolded, there would have been an interaction effect at play, whereby the weakness of the state (an opportunity structure) made it possible for actors bound by high in-group trust (a social organizational resource) to boost their capacity for collective violence by acquiring arms (a material organizational resource) through raids on state armories. That resource boost, in turn, would have allowed the newly-armed groups to place further pressure on residual state forces, thereby expanding the initial opportunity structures and creating further scope for violence.

While micro-level evidence of this feedback loop is currently limited, it is clear that -in short time -- a large number of state arms caches were overrun and looted, particularly in the south of the country, where the reach of the government was extremely limited (Robertson, 1997). As anti-government activists got their hands on a plentiful supply of weapons, progovernment authorities reportedly responded by throwing open arms caches in central and northern regions of the country, where Democratic Party sympathizers were based (AFP, 1997; Fischer, 1999, 297). Whether or not that was actually the case, it was estimated that some 1200 armories were penetrated across the country and, as such, more than 550,000 small arms passed into private hands, along with 1.5 billion rounds of ammunition, and 3.5 million grenades (Holtom \& et al., 2005, 6).

\section{The Outcome: A Chaotic, Violent Conflict}

As externally-imposed constraints on insurgency folded alongside the collapse of state capacity in early 1997, and the organizational resources for armed rebellion became available, diverse groups mobilized and armed to exploit the emerging opportunity space for violence. Some of the most prominent actors in the 1997 crisis were bands of organized criminals that had already formed prior to the collapse of state capacity (Quinn, 1997). Those existing bands, however, were soon joined by new armed groups that formed to provide neighborhood protection as the state withered (see Nicholson, 1999, 545; Spolar, 1997). They were also joined by the armed wings of "Salvation Committees", ${ }^{18}$ which were informal governance structures that emerged in the south of the country. These defense militias were typically led

\footnotetext{
${ }^{18}$ For a contemporaneous newspaper account of these defence units see, for example, Carassava (1997).
} 
by former military officers (Pettifer \& Vickers, 2007, 20), ${ }^{19}$ and staffed by networks of local men who shared close kinship and neighborly ties (Murphy, 1997). The same combination of ex-military and kin also populated armed groups that mobilized in support of a national-level fight for control of the government. For groups based in the south, the ostensible goal was to head to Tirana and remove Berisha. And for residual state forces and state-aligned militias in the north, the aim was to protect the incumbent government against the threat from rebel forces (see Pettifer \& Vickers, 2007, 40, 54-56; Walker, 1997).

With numerous groups under arms by March 1997, and no state actors able to mediate between those groups, violent conflict broke out. Although the exact dynamics of that conflict are disputed, observers tend to frame events in two ways. One set of authors emphasizes the political nature of the crisis, describing the events of 1997 as the first popular armed uprising in Europe since the $19^{\text {th }}$ Century (Fischer, 2010; Pettifer \& Vickers, 2007; Sunley, 1997). For these observers, the conflict pitted southern rebel militias allied with the Socialist Party (Biberaj, 1998, 350) against northern (state and non-state) armed groups that remained loyal to the incumbent government and Berisha (Perlez, 1997b). This reading contrasts with a second position, which sees the crisis of 1997 as a combination of organized criminal activity and disorganized, chaotic violence from a disaffected population. From this perspective, the most intense clashes involved rival organized criminal groups that were competing for the spoils of predation under conditions of anarchy (ICG, 1997; Nicholson, 1999; Abrahams, 2015). Tragic accidents were also responsible for a large number of causalities as men, women, and children who had no experience of using firearms shot weapons into the air without realizing the lethal consequences of falling bullets (Sweeny, 1997). Whatever the dynamics of violence, however, it is estimated that the mobilization of armed groups alongside the breakdown of order in Albania in 1997 resulted in over 2000 fatalities (Pettifer \& Vickers, 2007, 18; ICG 2000).

\section{Conclusion}

In this article, I have argued that the concept of 'opportunities' is over-aggregated and under-specified in the study of conflict and armed insurgency. As such, I have proposed a twofold clarification of the term. First, I have suggested that the idea of 'opportunities' should be disaggregated into two, discrete concepts: opportunity structures (which influence external constraints on insurgency) and organizational resources (which inform the internal capacity of insurgent groups). Second, in specifying the core characteristics of these disaggregated terms,

\footnotetext{
${ }^{19}$ This is also reported in contemporaneous news articles on the crisis. See, for example EIU (1997); Perlez (1997a).
} 
I have argued that we should recognize material/institutional and social/normative dimensions of each category.

To illustrate the potential benefits these conceptual revisions, I have used the proposed framework as a basis for exploring and explaining variation in the mobilization of armed groups and collective violence in Albania in 1991 and 1997. At both times, state capacity dissolved, creating broadly-defined opportunities for insurgency -- and yet those opportunities only translated into the mobilization of armed groups and violent conflict in 1997. While puzzling, that variation can be explained by taking a disaggregated approach. Specifically, disaggregation reveals that state dissolution lifted external constraints on the possibility for collective violence on both occasions. In 1991, however, potentially predatory and/or protective actors did not have access to the social networks that typically underwrite mobilization for collective violence or the material tools needed for armed action. In 1997, by contrast, dense social networks facilitated the mobilization of gangs and rebel groups, which then armed themselves by raiding state weapons caches, before using those arms to realize large-scale collective violence. Thus, the confluence and interaction of opportunity structures with organizational resources in 1997 allowed motivated actors to mobilize in support of collective violence for instrumental purposes, while the absence of organizational resources in 1991 contributed to the absence of collective violence at that time.

If treatment of the Albanian cases points to the potential benefits of conceptual clarification for academic analysis, then it is worth closing by considering whether such a clarification might also boost the policy relevance of opportunity-based approaches to the study of violent conflict. At present, that relevance is sometimes questionable. After all, the primary policy implication of broad opportunity-based arguments is that violent conflict can be reduced by closing down opportunities for insurgency. However, since it is not clear what conflict scholars actually mean by 'opportunities', it is also not clear exactly what should be closed down. Disaggregation and specification along the lines recommended here, however, points toward two sets of interventions that could limit violent conflict; one that would shut down opportunity structures by boosting externally-imposed constraints on insurgents, and another that would attend to organizational resources by interrupting the means that bellicose groups need to realize collective violence. When thinking through each of these approaches, policy actors may also benefit from considering a set of (possibly more pacific) interventions that would aim to challenge the social and normative underpinnings of collective violence, alongside (typically more forceful) attempts to manage and respond to the material/institutional feasibility of armed action. 


\section{Works Cited}

Abrahams, FC (2015) Modern Albania: From Dictatorship to Democracy in Europe. New York: NYU Press.

Adamson, FB (2005a) Globalisation, Transnational Political Mobilisation, and Networks of Violence. Cambridge Review of International Affairs 18(1):31-49.

Adamson, FB (2005b) Global Liberalism versus Political Islam: Competing Ideological Frameworks in International Politics. International Studies Review 7(4):547-69.

AFP (1997). Berisha Isolated as Albania Arms Militias to Restore Order. Agence France Press, March 15.

Ahram, A (2014) Can ISIS Overcome the Insurgency Resource Curse? Monkey Cage / Washington Post, July 2.

Amy, LE, \& Gjermeni, E (2013) Where is the 'State' in Albania? The Unresolved Contradictions Confronting Civil Society in the 'Transition' from Communism to Free Markets. Studies of Transition States and Societies 5(1):7-21.

Asal, VH et al. (2014) Building Terrorism from Social Ties: The Dark Side of Social Capital. Civil Wars 16(4):402-24.

Asal, VH et al. (2013). Gender Ideologies and Forms of Contentious Mobilization in the Middle East. Journal of Peace Research 50(3):305-18.

Bakke, K (2013) Copying and Learning from Outsiders? Assessing Diffusion from Transnational Insurgents in the Chechen Wars. In Checkel, J (ed.) Transnational Dynamics of Civil War. Cambridge: Cambridge University Press.

Ballentine, K \& Nitzschke, H (2003) Beyond Greed and Grievance. Policy Lessons from Studies in the Political Economy of Armed Conflict. New York: IPA Policy Report.

Bardoshi, N (2012) Albanian Communism and Legal Pluralism. The Question of Kanun Continuity. Ethnologia Balkanica 16:107-25.

Basedau, M \& Lay, J (2009) Resource Curse or Rentier Peace? The Ambiguous Effects of Oil Wealth and Oil Dependence on Violent Conflict. Journal of Peace Research 46(6):75776.

Battiata, M (1992) Albania's Post-Communist Anarchy; Crime, Looting Spread in Balkan Land Once Ruled by Terror. The Washington Post, March 21.

Behrakis, Y (1997) Rebels Try 'Traitors' as Albania Stumbles Closer to Civil War. The Independent, March 7.

Bezemer, DJ (2001) Post-Socialist Financial Fragility: The Case of Albania. Cambridge Journal of Economics 25(1):1-23.

Biberaj, E (1998) Albania in Transition: The Rocky Road to Democracy. Boulder: Westview Press.

Binder, D (1991) Albania's Hard-Liners and Democracy Backers Battle for Control. The New York Times, February 24.

Birch, J (1971) The Albanian Political Experience. Government and Opposition 6(3):361-80.

Buhaug, H et al. (2009) Geography, Rebel Capacity, and the Duration of Civil Conflict. Journal of Conflict Resolution 53(4):544-69.

Carassava, A (1997) Albania's Rebels Try to Create United Movement. Associated Press, March 7.

Cederman, L-E and Vogt, M (2017) Dynamics and Logics of Civil War. Journal of Conflict Resolution 61(9): 1992-2016.

Celik, AB \& Shkreli, A (2010) An Analysis of Reconciliatory Mediation in Northern Albania: The Role of Customary Mediators. Europe-Asia Studies 62(6):885-914. 
Chassagne, P \& Gjeloshaj, K (2001) L'émergence de la criminalité organisée albanophone. Cahiers d'Etudes sur la Méditerranée Orientale et le Monde Turco-Iranien (32):16290.

Collier, P \& Hoeffler, A (2004) Greed and Grievance in Civil War. Oxford Economic Papers 56(4):563-95.

Collier, P et al. (2009) Beyond Greed and Grievance: Feasibility and Civil War. Oxford Economic Papers 61(1):1-27.

Cramer, C (2006) Civil War is Not a Stupid Thing: Accounting for Violence in Developing Countries. London: Hurst \& Co.

Daly, E (1997) Looted Arms Fortify Rebels' Fighting Spirit. The Independent, March 8.

Della Porta, D (1988) Recruitment Processes in Clandestine Political Organizations: Italian Left-Wing Terrorism. International Social Movement Research 1:155-69.

Della Porta, D (2008) Research on Social Movements and Political Violence. Qualitative Sociology 31(3):221-30.

Denny, EK \& Walter, BF (2014) Ethnicity and Civil War. Journal of Peace Research 51(2): $199-212$.

Dine, P (1991) Albanian Leader Fears Anarchy: 'It's a Grave Situation' President Laments. St. Louis Post-Dispatch, November 5.

Driscoll, J (2015) Warlords and Coalition Politics in Post-Soviet States. Cambridge: Cambridge University Press.

EIU/Economist Intelligence Unit (1997) Albania Politics: Chaos. EIU ViewsWire, March 17.

Fearon, JD (2005) Primary Commodity Exports and Civil War. Journal of Conflict Resolution 49(4):483-507.

Fearon, JD \& Laitin, DD (1996) Explaining Interethnic Cooperation. American Political Science Review 90(4):715-35.

Fearon, JD \& Laitin, DD (2003) Ethnicity, Insurgency, and Civil War. American Political Science Review 97(1):75-90.

Fischer, BJ (1999) Albanian Highland Tribal Society and Family Structure in the Process of Twentieth Century Transformation. East European Quarterly 33(3):281-301.

Fischer, BJ (2010). Albania since 1989: The Hoxhaist Legacy. In Ramet, SP (ed.) Central and Southeast European Politics since 1989. Cambridge: Cambridge University Press.

Fowler, B (1992) Albania Searches for a Stable Future. The New York Times, February 16.

Fuga, A (2003) Les mots dans la communication politique en Albanie. Paris: L'Harmattan.

Galtung, J (1990) Cultural Violence. Journal of Peace Research 27(3):291-305.

Gamson, WA \& Meyer, DS (1996) Framing Political Opportunity. In McAdam D et al. (eds.), Comparative Perspectives on Social Movements: Political Opportunities, Mobilizing Structures, and Cultural Framings. Cambridge: Cambridge University Press.

Gerring, J (1999) What Makes a Concept Good? A Criterial Framework for Understanding Concept Formation in the Social Sciences. Polity 31(3):357-93.

Gërxhani, K \& Schram, A (2000) Albanian Political-Economics: Consequences of a Clan Culture. LICOS Discussion Paper 92/2000, University of Leuven.

Giugni, M (2009) Political Opportunities from Tilly to Tilly. Swiss Political Science Review 15(2):361-68.

Gledhill, J (2013) Assessing (In)security after the Arab Spring: Editor's Introduction. PS: Political Science and Politics 46(4):709-15.

Gledhill J (2017) When State Capacity Dissolves: Explaining Variation in Violent Conflict and Conflict Moderation. European Journal of International Security, 2(2):153-178.

Gleditsch, KS \& Ruggeri, A (2010) Political Opportunity Structures, Democracy, and Civil War. Journal of Peace Research 47(3):299-310. 
Goldstone J et al. (2010) A Global Model for Forecasting Political Instability. American Journal of Political Science 54(1):190-208.

Gonce, J (2009) Anne-Marie Autissier: 'Albania was the North Korea of Its Time'. Webpage, Retrieved on 7 July 2018 from https://cafebabel.com/en/article/anne-marie-autissieralbania-was-the-north-korea-of-its-time-5ae006fbf723b35a145e15d4/

Goodwin, J \& Jasper, JM (1999) Caught in a Winding, Snarling Vine: The Structural Bias of Political Process Theory. Sociological Forum 14(1):27-54.

Greenhill, K \& Major, S (2006/7) The Perils of Profiling: Civil War Spoilers and the Collapse of Intrastate Peace Accords. International Security 31(3):7-40.

Gurr, TR (1970) Why Men Rebel. Princeton, NJ: Princeton University Press.

Hegre, H et al. (2001) Toward a Democratic Civil Peace? Democracy, Political Change, and Civil War, 1816-1992. American Political Science Review 95(1):33-48.

Hendrix, CS (2010) Measuring State Capacity: Theoretical and Empirical Implications for the Study of Civil Conflict. Journal of Peace Research 47(3):273-85.

Herbst, J (2004) African Militaries and Rebellion: The Political Economy of Threat and Combat Effectiveness. Journal of Peace Research 41(3):357-69.

Holtom P et al. (2005) Turning the Page: Small Arms and Light Weapons in Albania. London: Centre for Peace and Disarmament Education and Saferworld.

Humphreys, M (2005) Natural Resources, Conflict, and Conflict Resolution: Uncovering the Mechanisms. Journal of Conflict Resolution 49(4):508-37.

Huntington, SP (1993) The Clash of Civilizations? Foreign Affairs 72(3):22-49.

ICG (1997) ICG Albanian Program: Preliminary Report. Brussels: International Crisis Group.

ICG (2000) Albania's Local Elections: A Test of Stability and Democracy. Balkans Briefing. Tirana/Brussels: International Crisis Group.

Irrea, D (2006) The Balkanisation of Politics: Crime and Corruption in Albania (EUI Working Paper, RSCAS, No. 2006/18). Florence: European University Institute.

Jarvis, C (2000) The Rise and Fall of Albania's Pyramid Schemes. Finance \& Development 37(1):Online. Retrieved on 7 August 2018 from http://www.imf.org/external/pubs/ft/fandd/2000/03/jarvis.htm

Jenkins, JC (1983) Resource Mobilization Theory and the Study of Social Movements. Annual Review of Sociology 9:527-53.

Kaldor, M (2006) New \& Old Wars. Cambridge: Polity.

Keck, ME \& Sikkink, K (1998) Activists beyond Borders: Advocacy Networks in International Politics (Ithaca, NY: Cornell University Press).

Kitschelt, HP (1986) Political Opportunity Structures and Political Protest: Anti-Nuclear Movements in Four Democracies. British Journal of Political Science 16(1): 57-85.

Koopmans, R (1999) Political. Opportunity. Structure. Some Splitting to Balance the Lumping. Sociological Forum 14(1):93-105.

Koopmans, R \& Olzak S (2004) Discursive Opportunities and the Evolution of Right-Wing Violence in Germany, American Journal of Sociology 110(1):198-230.

Korovilas, J (1999) The Albanian Economy in Transition: The Role of Remittances and Pyramid Investment Schemes. Post-Communist Economies 11(3):399-415.

Kubicek, P (1998) Another Balkan Humpty-Dumpty: Putting Albania Back Together. European Security 7(2):78-91.

Kuhn, A (2018) Explaining Ethnic Mobilization against Resource Extraction: How Collective Action Frames, Motives, and Opportunities Interact. Studies in Conflict \& Terrorism 41(5):388-407.

Lane, D (1998) Albania, March 1997: The Disintegration of the Albanian Military. The Mediterranean Quarterly 9(2):16-29. 
Lawson, C \& Saltmarshe, D (2000) Security and Economic Transition: Evidence from North Albania. Europe-Asia Studies 52(1):133-48.

Le Billon, P (2001) The Political Ecology of War: Natural Resources and Armed Conflicts. Political Geography 20(5):561-84.

Library of Congress, Federal Research Division (1994) Albania: A Country Study (edited by Zickel R \& Iwaskiw W) Washington, DC: U.S. Government Printing Office.

Lubonja, F (1997) Pyramids of Slime. Përpjekja, 10(Special Ed.):82-92.

Lujala, P (2010) The Spoils of Nature: Armed Civil Conflict and Rebel Access to Natural Resources. Journal of Peace Research 47(1):15-28.

Mahoney, J (2008) Toward a Unified Theory of Causality. Comparative Political Studies 41(4/5):412-36.

McAdam, D (1982/1999) Political Process and the Development of Black Insurgency, 19301970. Chicago: University of Chicago Press.

McAdam, D (1996) Conceptual Origins, Current Problems, and Future Directions. In McAdam $\mathrm{D}$ et al. (eds.), Comparative Perspectives on Social Movements: Political Opportunities, Mobilizing Structures, and Cultural Framings. Cambridge: Cambridge University Press.

McAdam, D et al. (2001) Dynamics of Contention. Cambridge: Cambridge University Press.

McCammon, HJ et al. (2007) Movement Framing and Discursive Opportunity Structures: The Political Successes of the U.S. Women's Jury Movements. American Sociological Review 72(5):725-49.

McCarthy, JD \& Zald, MN (1977) Resource Mobilization and Social Movements: A Partial Theory. American Journal of Sociology 82(6):1212-41.

McDoom, OS (2014) Antisocial Capital: A Profile of Rwandan Genocide Perpetrators' Social Networks. Journal of Conflict Resolution 58(5):865-93.

Meyer, DS \& Minkoff, DC (2004) Conceptualizing Political Opportunity. Social Forces 82(4):1457-92.

Murphy, B (1997) Patchwork of Leaders Rise from Rage in Southern Albania. Associated Press International, March 10.

Musaraj, S (2011) Tales from Albarado: The Materiality of Pyramid Schemes in Postsocialist Albania. Cultural Anthropology 26(1):84-110.

Nicholson, B (1999) The Beginning of the End of a Rebellion: Southern Albania, May-June 1997. East European Politics \& Societies 13(3):543-65.

Nordland, R \& Sullivan, S (1997) The Despised Ex-Hero. Newsweek, March 31.

Opp, KD (2009) Theories of Political Protest and Social Movements: A Multidisciplinary Introduction, Critique, and Synthesis. London: Routledge.

Parkinson, SE (2013) Organizing Rebellion: Rethinking High-Risk Mobilization and Social Networks in War. American Political Science Review 107(3):418-32.

Pashko, G (1993) Obstacles to Economic Reform in Albania. Europe-Asia Studies 45(5):90721.

Pearlman, W (2011) Violence, Nonviolence, and the Palestinian National Movement (New York: Cambridge University Press, 2011).

Perlez, J (1997a) Rebel Albania Port Prepares to Repel Government Attack. The New York Times, March 9.

Perlez, J (1997b) Bitter Albanians, Facing Anarchy, Arm Themselves. The New York Times, March 14.

Petersen, RD (2001) Resistance and Rebellion: Lessons from Eastern Europe. Cambridge: Cambridge University Press.

Pettifer, J \& Vickers, M (2007) The Albanian Question: Reshaping the Balkans. London: I.B. Tauris. 
Quinn, P (1997) In Lawless Albanian South, Bandits Rule the Land. Associated Press International, March 21.

Raufer, X (2003) A Neglected Dimension of Conflict: The Albanian Mafia. In Koehler, J \& Zürcher, C (eds.), Potentials of Disorder. Manchester: Manchester University Press.

Reuters (1992) Official in Albania Sees Anarchy as Rioting and Looting Continue. The New York Times, March 1.

Robertson, J (1997) Albania Declares Emergency; Rebels are Told to Surrender Arms or Be 'Shot without Warning'. The Guardian, March 3.

Ron, J (2005) Paradigm in Distress? Primary Commodities and Civil War. The Journal of Conflict Resolution 49(4):443-50.

Ross, ML (2004) How Do Natural Resources Influence Civil War? Evidence from Thirteen Cases. International Organization 58(1):35-67.

Rotberg, R (2004) The Failure and Collapse of Nation-States. In Rotberg, R (ed.), When States Fail: Causes and Consequences (Princeton: Princeton University Press).

Sadiku, M (2014) The Origins of the Kanun: Exploring the Development of the Albanian Customary Law. Balkan Araştırma Enstitüsü Dergisi 3(2):77-95.

Sambanis, N (2004) Using Case Studies to Expand Economic Models of Civil War. Perspectives on Politics 2(2):259-79.

Sanín FG \& Wood EJ (2014) Ideology in Civil War: Instrumental Adoption and Beyond. Journal of Peace Research 51(2):213-26.

Santoro, L (1997) Civilian Revolt in Albania: Rage Gives Rise to Militias. Christian Science Monitor, March 10.

Sartori, G (1970) Concept Misformation in Comparative Politics. American Political Science Review 64(4):1033-53.

Schock, K (2005) Unarmed Insurrections: People Power Movements in Nondemocracies. Minneapolis: University of Minnesota Press.

Schwandner-Sievers, S (2001) The Enactment of 'Tradition': Albanian Constructions of Identity, Violence and Power in Times of Crisis. In Schmidt, BE \& Schröder, IW (eds.), Anthropology of Violence and Conflict. London: Routledge.

Sharp, G (1959) The Meanings of Non-Violence: A Typology (Revised). Journal of Conflict Resolution 3(1):41-66.

Smith, H (1991) Feuding Albania Destroys Itself. The Guardian, September 24.

Smith, T (1991) Communists Win Leaves Albania More Polarized, Violence Possible. The Associated Press, April 1.

Snyder, D \& Tilly, C (1972) Hardship and Collective Violence in France, 1830 to 1960. American Sociological Review 37(5):520-32.

Sobek, D (2010) Masters of their Domains: The Role of State Capacity in Civil Wars. Journal of Peace Research 47(3):267-71.

Spolar, C (1997) Albanian Leader Offers Olive Branch to Protesters. The Washington Post, March 7.

Staniland, P (2012) Organizing Insurgency: Networks, Resources, and Rebellion in South Asia. International Security 37(1):142-77.

Sunley, J (1997) Disorder in Albania. The New York Review of Books, December 4.

Sweeny, J (1997) Cut Down by a Hard Deadly Rain. The Observer, March 16.

Tansey, O (2016) The International Politics of Authoritarian Rule. Oxford: Oxford University Press.

Tarifa, F (1994) The Human Dimension of De-Communization in Post-Communist Societies. Helsinki Monitor 5(2):60-67.

Tarrow, S (1998) Power in Movement: Social Movements and Contentious Politics. Cambridge: Cambridge University Press. 
Taydas, Z et al. (2011) Why Do Civil Wars Occur? Another Look at the Theoretical Dichotomy of Opportunity versus Grievance. Review of International Studies 37(5): 2627-50.

Tilly, C (1977) From Mobilization to Revolution. CRSO Working Paper \# 156. Ann Arbor: University of Michigan. Retrieved on 6 August 2018 from: http://deepblue.lib.umich.edu/bitstream/handle/2027.42/50931/156.pdf

Traynor, I (1991a). Government of Albania Collapses. The Guardian, June 3.

Traynor, I (1991b) Coup Rumours Sweep Tirana as Four Reported Killed in Clashes. The Guardian, February 23.

Traynor, I (1991c) Albanian Tanks on Streets as the Protests Continue. The Guardian, February 22.

Turku, H (2009) Isolationist States in an Interdependent World. Farnham: Ashgate Pub, Co.

Turton, D (1997) Introduction: War and Ethnicity. In Turton, D (ed.) War and Ethnicity: Global Connections and Local Violence (Rochester: Boydell Press).

Vickers, M (2009) The Albanians: A Modern History. London: I.B.Tauris.

Vickers, M \& Pettifer, J (1997) Albania: From Anarchy to a Balkan Identity. London: C. Hurst $\&$ Co.

Walker, T (1997) Berisha Loyalists Raise Spectre of North-South War. The Times, March 12.

Watkins, JWN (1952) Ideal Types and Historical Explanation. The British Journal for the Philosophy of Science 3(9):22-43.

Watson, F (1997) Albania, Research Paper 97/59. London: International Affairs and Defence Section, House of Commons Library.

Weber, M (2004) The 'Objectivity' of Knowledge in Social Science and Social Policy. In Whimster, S (ed.), The Essential Weber: A Reader (London: Routledge)

Weinstein, JM (2007) Inside Rebellion: The Politics of Insurgent Violence. Cambridge: Cambridge University Press.

Zanga, L (1991) Military Undergoes Reforms. RFE/RL Report on Eastern Europe 2(46):1-3. 